Supporting Ghanaian micro-entrepreneurships: The role of mobile technology

Emmanuel Mensah Asiedu

Oxford Brookes University

Headington Campus

Oxford,

OX3 0BP

Dr Susan Shortland*

University of Westminster

35, Marylebone Road

London

NW1 5LS

Yehia Nawar

University of West London

Paragon House

Boston Manor Road

Brentford

TW8 9GA

Dr Paul Jackson

Oxford Brookes University

Headington Campus

Oxford,

OX3 0BP

Laura Baker

University of Southampton

University Road

Southampton

SO17 1BJ

*Corresponding author 


\title{
Supporting Ghanaian micro-entrepreneurships: the role of mobile technology
}

\begin{abstract}
Purpose

The purpose of this paper is to explore the role of mobile technology and related service platforms in supporting informal micro-entrepreneurships in rural Ghana. It aims to extend our knowledge through the development of a conceptual model.
\end{abstract}

\section{Design/Methodology/Approach}

A qualitative research design used in-depth semi-structured interviews with five microentrepreneurship owners in the Kwahu South District in the Eastern region of Ghana. Identification of potential case firms was facilitated by a local official. Interview data were analysed thematically.

\section{Findings}

Mobile technology engendered pride and emotional connectedness and, being easy to use, helped to increase business confidence. Adoption advantages included improved communications with customers and business partners, and effective stock control, providing competitive advantage. Further understanding of mobile technology's role in improving business processes is needed.

\section{Research limitations/implications}

This exploratory research is based on five micro-entrepreneurships in one Ghanaian rural area. Further research is needed using larger samples, additional locations and sectors, and larger businesses, to identify other factors influencing mobile technology adoption and associated benefits and problems.

\section{Practical implications}

Government policy supporting growth of informal micro-entrepreneurships using mobile phone technology could increase economic advantage. Micro-business owners need education and training in understanding business processes. Telecommunications companies can highlight technological, business and socio-cultural benefits of mobile phone adoption in rural Ghana. 


\section{Originality/Value}

The paper draws upon the experiences of a range of rural-based Ghanaian microentrepreneurships to propose a model setting out and linking the technical, business and socio-cultural benefits of mobile phone adoption in supporting business processes.

Keywords: Mobile phones; internet-based entrepreneurship; platform technology; competencies; informal micro-entrepreneurships; Ghana.

Article classification: Research Paper. 


\section{Supporting Ghanaian micro-entrepreneurships: the role of mobile technology}

\section{Introduction}

The African economy is dependent on micro-, small and medium scale entrepreneurships (SMEs) (Grant, 2013). Micro-entrepreneurships, which typically employ up to five people and have less than $\$ 100,000$ assets (Kusi et al., 2015), are important because they create jobs, pay taxes and sustain the economy (Ameyaw et al., 2016). They also serve as major links in the supply chain and as corporate entities (Obeng et al., 2014). In addition, their activities support exports thereby contributing to foreign exchange from international markets (Amoako and Matlay, 2015).

In Ghana, micro-entrepreneurships provide around half of manufacturing, catering, cleaning and other services within the agro-based and retail sectors (Tetteh and Frempong, 2013). The overall contribution of micro-entrepreneurships and SMEs together comprised some 50\% of GDP in 2010 (Ghana Statistical Service, 2012), rising to 70\% in 2017 (Today Online, 2017). In addition to GDP, micro-entrepreneurships contribute to revenue generation through employment and sales (Kwakwa, 2012). For example, micro-businesses, such as pineapple farmers and cashew farmers, produce and sell goods to agents who add value through cleaning and packaging before selling to exporters who sell on for foreign exchange earnings, thereby further contributing to the economy (Amoako and Matlay, 2015).

Over $45 \%$ of the population in Ghana live in rural areas and rely heavily on microentrepreneurships, particularly within agriculture and retail. Micro-entrepreneurships support national economic growth, providing about $70 \%$ of Ghana's employment. Mostly comprising sole traders or partners, over $55 \%$ of micro-entrepreneurships operate informally in rural areas supporting subsistence livelihoods. The remainder are based in towns and villages (Adom and Williams, 2014). Ghana's micro-entrepreneurships are unrecognised by formal or governmental institutions (Osei-Boateng and Ampratwum, 2011) and unsupported by policy makers (Boafo et al., 2015). In essence, they fall under the radar of policymakers, economists and international organisations (Kwakwa, 2012).

Ghana's rural micro-entrepreneurships face considerable problems such as a lack of good roads, electricity and telecommunications facilities. Thus, most business owners in these areas rely on mobile phones for communication and to support their business processes. In essence, technological resources are crucial for the survival of this sector (Acheampong and Hinson, 2018). Indeed, Ghana has seen strong growth in the use of the mobile phones over the past 10 years, with mobile phone penetration reaching $80 \%$ in 2015 (ITU, 2017), 
highlighting the importance of mobile phone technology and people's reliance upon it. Yet, despite the crucial economic contribution of informal micro-entrepreneurships in Ghana, we know little about how they operate their businesses using mobile phone technology. This is clearly a major gap in our knowledge because an understanding of the use of technology by these burgeoning micro-enterprises could help policy-makers and commercial institutions to support these vital economic contributors more effectively. For example, we currently know little about the communications tools that rural Ghanaian micro-entrepreneurs use to facilitate their business processes, the factors that drive the adoption of mobile phone technology, the availability and reliability of mobile phones and related platforms and, once adopted, how mobile technology enhances micro-entrepreneurs' business processes. An understanding of the problems that micro-entrepreneurships face could also assist in supporting this sector of the economy going forward.

To address these issues, this paper aims to explore the role of mobile technology and related service platforms in supporting micro-enterprises in the Kwahu South District in the Eastern Region of Ghana. Based on an exploratory qualitative study undertaken via in-depth interviews, it examines the use of mobile phones as a business tool in five informal microenterprises: baking; bee keeping/honey making; herbal and medical treatment; palm oil and kernel extraction; and tailoring and dressmaking. The paper's objectives are two-fold. First, it sets out to extend our knowledge of mobile phone technology in developing countries through the development of a conceptual model. This model builds upon known technological and business benefits of mobile phone adoption by linking these to the sociocultural context of informal micro-entrepreneurships in rural Ghana. The paper's second objective is to highlight implications for practice which can be used by policy-makers and commercial firms to help support the technological resources needs of informal microentrepreneurships in rural Ghana. To support these research objectives, the study addresses the following research questions:

1. Which factors influence the adoption of mobile phone technology by informal microentrepreneurships in rural Ghana?

2. Which mobile phones/platforms are used to support informal micro-entrepreneurships in rural Ghana?

3. How does mobile phone technology support informal micro-entrepreneurships' business processes in rural Ghana? 
4. What problems do informal micro-entrepreneurships in rural Ghana encounter in using mobile phone technology and related platforms to support their business processes?

\section{Literature Review}

\section{The Mobile Phone and its Usage in Africa}

The mobile phone is a simple, easy-to-use, portable device that is wireless, handheld and allows users to make telephone calls. It is also used to send texts (short message services or SMSs). Current models, known as smartphones, are more technologically advanced, enabling access to the internet, facilitating learning, and can be highly personalised. Individuals' attachment and connection to their phone depends upon the brand, country of origin and design (Buys et al., 2009). Today, people regard mobile phones as essential due to the various services they provide to individuals and businesses. For example, businesses like banks are able to send messages on accounts and payments to customers (Sey, 2011). In addition, Odoom et al. (2017) also posit that mobile phones have become essential to our daily lives as a result of being used for social media purposes and note that SMEs have realised this opportunity with some using social media to build relationships with their customers.

In newly industrialising countries, mobile phones play an important role in bridging the gap between cities and rural areas and are adaptable in facilitating business processes. Mobile phones are especially important in areas which lack infrastructural facilities such as landline telephone systems (Aker and Mbiti, 2010). The freedom offered by mobile phones enables users to conduct business with customers by taking orders and making sales, diarising appointments, and providing diagnostic responses to clients wherever they are. In areas where internet facilities are available, smartphones provide an opportunity for businesses to expand into e-commerce and m-commerce services (Asongu, 2013a), although as Aker and Mbiti (2010) indicate, for people in rural areas, smartphones can be redundant if there are no internet facilities. The technological and business benefits of mobile phone adoption are summarised in the shaded boxes in Figure 1.

- Take in Figure 1 around here -

The most popular mobile phones used on the African continent are Nokia and Samsung devices (Asongu, 2013b). Other notable manufacturers whose phones are used 
include Alcatel, Lenovo and, recently, Hisense. These companies are known to provide mobile phones that are cheaper, have long battery life and support the necessary applications used in the rural areas by small businesses including voice and messaging. These handsets facilitate call communications and information sharing which, in turn, helps to reduce costs, for example from transportation (Jack and Suri, 2014).

In Ghana the most notable telephony companies are Vodafone, MTN, Glo, Tigo, Zain and Airtel. MTN holds around $43 \%$ of the market share (Akanferi et al., 2014). Manufacturers produce handsets for telecommunication companies, with handsets manufactured with the changing customers' needs and the pace of technology in mind. Thus, manufacturers work in close contact with application developers - especially for smartphones - to ensure they provide applications that benefit mobile phone users in areas of banking, transportation and entertainment (Hall and Anderson, 2009). In developing countries, including Africa, applications are available on smartphones which are used mainly in cities where internet facilities are available.

Today, a mobile phone is not the luxury product it was in the past (Akanferi et al., 2014). People of different ages, classes, and with different incomes have at least one mobile phone (Awiagah et al., 2016). The use of mobile phone technology cuts across demographics; everyone can use it in as much as they can have access or can buy one (Acheampong et al., 2014). Survey research into mobile phone ownership and usage in Ghana, Kenya, Uganda, Tanzania, Nigeria, Senegal and South Africa indicates mobile phone ownership of $34 \%$ in South Africa and 27\% in Nigeria. Smartphones are common in terms of usage in Nigeria and South Africa, but older models (such as the Nokia and Samsung brands) are typically used in countries such as Senegal, Uganda, Tanzania and Ghana. Mobile phones are used by individuals and businesses for a variety of purposes, including checking stocks and the prices of produce (PEW Research Center, 2015) and there is a relationship between access to networks and benefits and technology acceptance, especially by users such as entrepreneurs (Acheampong and Esposito, 2014). Smartphones, particularly thanks to their software-based operating systems, also provide a platform that facilitates the day-to-day activities of their users, for example in sending messages, reviewing prices, sending and receiving money, and advertising for products and services (Morgan and Govender, 2016).

Despite the positive benefits from mobile phone technology, Pierskalla and Hollenbach (2013) argue that the spread of violence during the Arab Spring in many African countries (especially in North Africa, then spreading to the Middle East) was facilitated 
through mobile phone usage and social media. In addition, Duncombe (2012) argues that the negative impact of the mobile phone should be taken into consideration in areas of security.

\section{Mobile Platforms and Ecosystems}

Various writers define platforms from different perspectives. For example, West and Wood (2014) describe platforms as architecture enabling the substitution of complementary software and hardware. Lin and Ye (2009) consider platforms as keystone firms forming part of an ecosystem. The term platform is thus used as a metaphor as well as a construct in management research (Thomas et al., 2014). The term platform is used most in high-tech companies and those which use technology to support their operations, as well as in a range of contexts such as investment platforms, technology platforms, and supply chain platforms (Gawer and Cusumano, 2014). Platforms are also discussed, from the perspective of organisations, as subsystems and interfaces that form a structure, based on which companies can develop products and services (Cusumano and Nobeoka, 1998; Krishnan and Gupta, 2001; Meyer and Lehnerd, 1997). Roberston and Ulrich (1998) define platforms from the broader perspective of the knowledge, assets, relationships, components and processes which are shared by a set of products and/or services, for example mobile money platforms which support the transfer of money using mobile technology. Krishnan and Gupta (2001) see platforms also as ecosystems. As such the mobile phone is not a standalone technology that provides communication services; it works within a system of inter-related technological activities (Sørensen et al., 2015).

The application of the ecosystem metaphor originated from the works of Moore (1993) who referred to ecosystems as loose business communities. Moore (1993) further indicated business ecosystems as socially evolving, working collectively to provide value for customers. Hence, an ecosystem consists of interrelated firms, players or group of companies that support the delivery of products and services (Basole and Karla, 2011). Literature also discusses ecosystems from the viewpoint of information technology: Xia et al. (2010) define an ecosystem as a network of actors. This includes mobile devices, network operators, application developers, and mobile phone manufacturers for example, Samsung, Apple and Nokia (Rao, 2012).

Mobile ecosystems can be analysed from three strands - processes, manufacturers, and operating systems (GSMA, 2014), although empirical studies on platforms and innovation ecosystems have focused on the computer and telecommunications industries in the main (Greenstein, 2009). Ciborra (1996) has also examined platforms in terms of their 
usage in facilitating business processes, from which specific structures are developed during organisational transformations and restructuring. Platforms here are seen to help mould the structure of the organisation, and thereby shape strategy. The platform, as part of the operating system within a mobile phone, facilitates smooth running and ease of use and controls the phone's applications. Platforms are developed to support customer needs either by facilitating the way a service is provided or by helping to modify the needs of existing product features to meet customers' needs (Wheelwright and Clark, 1992). Gawer (2014) indicates that there two main types of mobile platforms: internal and external.

Internal platforms include, for example, the Symbian OS, Android, Bada, Apple iOS, Blackberry and Windows operating systems, and facilitate the use of the mobile phone, enabling it to perform its functions (Hyrynsalmi et al., 2014; Wenner et al., 2017). The literature on internal platforms reports on the benefits of: minimising costs; gains in effective and efficient ways of production and service provision; supporting improvements in the technical aspect of the business; and the enjoyment of economies of scale (Pine, 1993). An important aspect of the internal platform, which supports business processes in facilitating the movement of goods and services, is the supply chain platform (Tierney et al., 2000).

The difference between the internal and the external platforms is that whereas the internal platforms are set within a particular company or organisation, external platforms are open to outside companies. External or industry platforms are thus developed as products or services that provide a foundation, based upon which other firms can innovate or build their products and services. These platforms therefore can form part of organisations' business models, facilitating development and growth processes (Wenner et al., 2017). It should be noted though that how open these external platforms are depends on issues such as regulations, costs and licensing (Boudreau and Hagiu, 2009). Examples of external/industry platforms are Linux Operating Systems, IOS operating Systems for Apple, Google Internet Search Engine and Android Operating Systems for smartphones. Others are the social media platforms like Facebook, Twitter and LinkedIn.

Taking the discussion on external platforms to another level, Gawer (2014) posits that the position of platforms within ecosystems changes once a new, more innovative platform emerges. Therefore, the scope of innovation is always evolving leading to the development of new platforms and the opening up of existing ones. This creates change within information systems in organisations as they accommodate the ever-evolving innovations. Users of mobile phones benefit, particularly small business entrepreneurships, due to the new business and service possibilities these open up (Hyrynsalmi et al., 2014). In essence, as the mobile 
technology environment keeps evolving, so do the actors in the network (Xia et al., 2010). In summary, platforms help to strengthen competitive scope enabling businesses to take advantage of new opportunities.

\section{Platforms in Ghana}

Literature on mobile platforms in developing countries such as Ghana centres around education, health, money transfers and on agriculture, but is limited on trade for informal micro-entrepreneurships (Furuholt and Matotay, 2011). For example, these platforms facilitate the transfer of messages to patients in their local language as to when to take their medicines or visit local health centres when necessary. In the areas of agriculture, platforms facilitate exchange of information on market prices and weather conditions (Esoko, 2015).

In addition, there are other platforms in Ghana which address social and educational issues. For example, STAR Ghana is a multi-donor funding platform (DFID, 2016). It was created as a social forum for Ghanaians to discuss election issues and to educate themselves on free and fair elections. The Agoo multilingual platform has been created in conjunction with the government of Ghana to educate rural people on the need for hand-washing to help prevent diseases such as cholera and Ebola. Agoo acts as a call centre where trained agents respond to calls. It has Interactive Voice Response (IVR) and it also provides SMS messages in local languages (Unicef stories of innovation, 2015). Etsy.com is the only trade platform that supports the sale of handmade cultural Ghanaian clothing, accessories, art sculptures and other paraphernalia. This platform has the characteristics of eBay and Amazon, where designers and manufacturers can register and sell their items. These platforms have developed as a result of Ghana's political stability and competitive markets, which have attracted businesses including telecommunications (National Communications Authority, 2016).

\section{Micro-entrepreneurships - Definitions and the Ghanaian Context}

According to the Report of the Committee of Enquiry into Small Firms (Bolton, 1971), the accepted definition of micro-entrepreneurships is based on the size of the business, its income and assets. For example, in India, micro-entrepreneurships are discussed as having fewer than 10 employees with assets of around $€ 2$ million, while a medium scale business is explained as having up to 250 employees with sales turnover of up to $€ 50$ million. The United States considers SMEs to include businesses of fewer than 500 employees, whereas China considers 
micro-, small and medium enterprises as businesses with from 1-3,000 employees (International Finance Corporation, 2011).

While the legal definition of micro- scale enterprises varies by industry and country, they typically employ up to five people and have less than $\$ 100,000$ assets; small business entrepreneurships employ between six and 29 people, with assets up to $\$ 200,000$, while medium scale businesses employ 30 and above and have assets up to \$1million (Kusi et al., 2015). These classifications are supported by the Independent Evaluation Group (IEG), whose definition also takes into consideration the metrics of income, size of business and turnover as well as giving consideration to occupational, behavioural and outcomes (IEG World Bank, 2014).

The Ministry of Trade and Industry (MOTI) classified SMEs in Ghana under micro-, small and medium scale enterprises by reference to the indicators in the Report of the Committee of Enquiry into Small Firms (Bolton, 1971) and also by making reference to the IEG Report (IEG World Bank, 2014). For example, micro-businesses are considered to employ up to five people with assets of not more than $\$ 100,000$; medium scale enterprises employ between 30-99 people with fixed assets of up to \$1million (Kwakwa, 2012).

Scarborough and Zimmerer (2011) posit that entrepreneurship concerns assembling the resources available in the face of risks and uncertainties, normally when opportunities are identified. Ghana does not lack entrepreneurship talents, as is the case in many other African countries. People are commonly seen engaging in numerous forms of business activity, with businesses starting as micro-entrepreneurships and then developing to become medium scale and then larger enterprises (Acheampong and Esposito, 2014). Micro-entrepreneurships form part of SMEs which, in turn, make a significant contribution to employment within various industries. In Ghana, SMEs employ over $70 \%$ of the population and cover many sectors, including poultry farming (Acheampong, 2018). Charles et al. (2015) posit that the SMEs shape the developmental agenda of countries by creating employment and contributing to countries' taxes and GDP. Where SMEs are predominantly in rural areas, they help reduce rural-urban migration by creating jobs for local people. This is supported by Frempong (2009) who indicates that SMEs contribute to development in Ghana by providing incomes for many families, thereby helping to improve people's livelihoods, as well as through being active in the value chain of many large organisations. Indeed, most SMEs in Ghana also produce for local consumption as well as export which also helps to bring in additional foreign investment to Ghana (GIPC, 2017). 
However, the growth of many SMEs is restricted due to lack of supporting resources (Acheampong and Hinson, 2018). The Ghanaian Government's trade liberalisation policy encouraging foreign companies also results in strong competition to local SMEs (Domeher et al., 2017). Most local SMEs in rural areas lack good quality roads to enable transport of their products, technological support to facilitate business activities and good governance to enable implementation of Government policy intended to regulate and manage the sector (Ocloo et al., 2014). In 1991, the Government of Ghana promulgated the PNDC Law 328 to allow financial institutions, financial non-governmental organisations and credit union associations to provide a diverse range of financial services to support micro- and small enterprises. However, unstable macro- and micro-economic conditions mean that SMEs are unable to access the finances they need in addition to necessary infrastructure (Charles et al., 2015).

In spite of these problems, SMEs contribute greatly to socio-economic development with informal micro-entrepreneurships playing a major role as micro-agency entrepreneurs, connecting businesses directly to economic outcomes (Wennekers and Thurik, 1999). For example, in India, micro-entrepreneurships contribute about $20 \%$ of the gross domestic product (GDP), $45 \%$ of the industrial output, and create some 1.3 million jobs annually (Islam and Grönlund, 2011). Hence, there has been the realisation that it is not just only large organisations that provide growth and support for developing and developed nations in terms of economic development; but SMEs, including micro-entrepreneurships within the formal and the informal sectors, do so as well.

\section{Formal and Informal Micro-entrepreneurships in Ghana}

Micro-entrepreneurships in Ghana in the formal sector are registered, have well-organised systems and pay taxes to the government. Examples include registered herbal medicinal companies, the Accra Association of Rattan Manufacturers, rural agro-based companies, registered retail companies, supermarkets and stalls, forest product workers, small cleaning companies, local alcohol manufacturers, local clinics and local automobile garages (OseiBoateng and Ampratwum, 2011).

Informal entrepreneurships also contribute to the calculated Gross National Product but are unregistered. This sector is also described as an unregulated sector (Hart, 1970; OseiBoateng and Ampratwum, 2011). In addition, Adom and Williams (2014) describe this market as the "black market", the "underground market", or the "cash-in-hand market", with this micro-sector including taxi drivers, transport owners, porters, mobile phone repairers, caterers, auto mechanics, car washing bays, small stall operators, sellers of mobile phone 
accessories, and small-scale supermarkets. According to Osei-Boateng and Ampratwum, (2011), micro-entrepreneurships in the informal sector include intermediary service providers that support most organisations' value chains, such as suppliers of raw materials to manufacturers with micro-entrepreneurs being either self-employed or working in partnerships. In rural areas, micro-entrepreneurships focus on agriculture (55\%) and retailing, including table-top markets and hawking (45\%) (Ghana Statistical Service, 2012).

\section{Methodology}

A qualitative case study approach was adopted (Yin, 2013) for this research study. The approach taken sought to elicit information on user behaviour in relation to learning, experience and usage of mobile phone technology (Amoako and Matlay, 2015) by five informal micro-entrepreneurships in the Kwahu South District of Ghana.

Primary data collection was conducted using in-depth, semi-structured interviews to learn of participants' experiences, expectations and thoughts on programmes, processes and outcomes (Boyce and Neal, 2006). Specifically, the research method set out to determine whether, and in what ways, mobile phones and related platforms are interpreted as a resource supporting informal micro-entrepreneurships in Ghana. The use of company case studies and semi-structured in-depth interviews with key managers enabled the collection of detailed information (Oliver and Kandadi, 2006) on mobile phone usage, the factors influencing the adoption of mobile phone technology, its influence on informal micro-entrepreneurship business processes, and the problems encountered in the use of mobile technology. The semistructured interview schedule is given in Appendix 1.

The researcher conducting the interviews is a native of the Kwahu South District of Ghana, having family ties within the district, and being fluent in the local language. The first step involved making contact with the Kwahu South District Assembly offices at Mpraeso to outline the benefits that the research could bring to local informal micro-entrepreneurships. The research project was seen to be beneficial to the local economy and thus a local officer was allocated to assist the researcher. This official acted as a gatekeeper for the research by making contact with informal businesses, explaining the purpose of the research and providing reassurance that the researcher was independent, not being linked to any form of government tax investigation. Although 20 businesses were identified by the gatekeeper as potentially being accessible, five informal micro-entrepreneurships were selected using purposive sampling (Bryman and Bell, 2015). 
The five businesses were selected based on feasibility of access by local transportation to the business site, willingness of the business personnel to engage in the interview, and these personnel actually having access to a mobile phone and using it for business purposes (Tongco, 2007). The selected businesses represented the following industries: baking; bee keeping; herbal medicine clinics; palm oil production; and tailoring and dressmaking. The business owners interviewed comprised three women and two men, all semi-literate, aged between 38 and 55. All employed between two and five staff. Background case study details are given in Appendix 2.

The owner-managers of these businesses were briefed on the interview process and given further reassurance that information provided would not be used for government or taxation purposes. Each business owner-manager interview was tape-recorded and lasted for approximately 45 minutes. Each interview was transcribed and, to preserve confidentiality, no real names or personal data by which individuals could be identified were used. Instead, individuals were represented by the type of business in which they were engaged. The interview transcripts were analysed using MS Word using colour coding and recurring patterns and themes in the data were recorded (Braun and Clarke, 2006).

All of the five businesses had adopted mobile phone technology. Linked to the research questions, the following themes were identified within the data:

- Factors influencing adoption: no land-lines; ease of use; gaining on competitors.

- Mobile technology used: Tecno SQ16 and SQ15; Nokia; Samsung; WhatsApp; Facebook.

- Business process support: sales support; customer/business partner communications; stock taking; ordering logistics; use as a diary; client diagnostics.

- Problems encountered: network issues; cost of credits.

In addition, a number of emergent themes were recorded which highlight socio-cultural aspects of mobile phone adoption: belief in the benefits that phone technology brings; a sense of pride; positive attitudes (a 'feel good' factor); and wider business and social communications.

\section{Findings}

This section presents the research findings in relation to the factors influencing the adoption of mobile phone technology, the phone and technology platforms used, the business processes supported by this technology, the problems encountered in using mobile phone 
technology, and the emergent issues identified by the five informal micro-entrepreneurships. The key messages from the data are summarised in this section with representative quotations presented to illustrate these issues in Table 1.

- Take in Table 1 around here -

\section{Factors Influencing the Adoption of Mobile Technology}

The informal micro-entrepreneurships were located in villages and remote towns, none of which had land-line facilities and some did not have reliable access to electricity. They reported that mobile phone technology was cost-effective compared with the process and cost of obtaining a land-line connection. Access to infrastructure was thus a major influence on decision-making regarding the adoption of mobile phone technology. The findings indicated that all of the entrepreneurs found mobile phone technology easy to use regardless of their level of education. They said that the mobile phone was a simple gadget, easy to carry, and did not require a complex learning process, specialist skill or knowledge to use effectively.

All of the respondents (excepting the herbal clinic owner, who did not have direct competition locally) also indicated that they believed that their adoption of the mobile phone gave them an advantage over their competitors who did not use mobile technology in conducting business. The findings further indicated that the informal micro-entrepreneurship owner-managers adopted technology which they believed would be beneficial to the growth of their businesses. Being owner-managers meant that the decision to adopt technology lay with them - as such, firm size can be thought to play a role in mobile technology adoption. Ease of acquisition and the environmentally-friendly nature of the mobile phone were also cited as reasons for its adoption.

\section{Mobile Phone Technology and Platforms}

Phones such as the Tecno SQ16 and SQ15 with longer battery life were the most commonly owned phones. The entrepreneurs owned more than one phone, usually having the SQ16 which is a basic, multiple sim, rugged model with clear lines of communication, plus a smartphone which is internet accessible to enable them to access social networks and communicate, for example via WhatsApp. The informal micro-entrepreneurs were not specifically aware of mobile phone platforms, although they sometimes sent messages to clients using them. For instance, the bee keeping business owner and the tailoring and dressmaking business owner both reported sending and receiving messages via WhatsApp, 
although they were unaware that this was a platform. The owner of the bakery business commented that she had heard of Facebook but did not know if it could help her to improve her business. The owner of the tailoring and dressmaking business indicated that she had used Facebook to look at design pictures, but she was unsure of its business benefits.

\section{Mobile Phone Technology and Business Processes}

While the research sought to find commonalities in business processes supported through mobile phone technology used by the informal micro-entrepreneurships, the findings indicated that every firm had a different business process. Nonetheless, the owner-managers were able to comment on some aspects of this, even if they could not articulate their business process in full sequence. Only one business owner-manager was able to explain how the mobile phone supported each stage of the business process used. The herbal clinic owner explained that she used the mobile phone in three process stages of her business. The first process concerned managing enquiries. She reported that patients called her to report ailments via the phone. She then conducted a 'pre-diagnosis' over the phone, giving advice before booking the patient in for a consultation. When clients have problems with medicines given, especially when they experience a reaction, she said that she used the mobile phone to advise them on whether to reduce/increase the dosage or change the times when they take the medicine. Finally, for customer service purposes and payments, she used the mobile phone for money transfers and to receive mobile money.

However, there was a lack of clarity amongst the other entrepreneurs in relation to their understanding of the role played by mobile phones and related platforms in supporting their business process stages. For example, the tailoring and dressmaking business owner reported that she received details of the materials required, the measurements of her clients, as well as their style choices via mobile technology and sewed accordingly, indicating that access to mobile technology helped in the process of making clothes. The bakery owner reported on baking tea and sugar breads according to the sizes and expectations of the customers but was also unable to reflect upon the role of the phone in each stage of the business process. In contrast, the palm oil processing business owner was able to articulate his business process but not the role that the mobile phone played in each part of it.

\section{Problems Associated with Mobile Phone Usage}

The findings indicated that the informal micro-entrepreneurs did face some problems in using mobile phone technology. In spite of the support that it gave to their businesses, issues 
identified included problems with battery life, power outages - which sometimes made it difficult to use a charging point - and the costs associated with buying mobile credits. Other issues raised included problems with the clarity of calls - resulting from network issues given the mountainous terrain - and weather conditions which made it difficult to receive and make calls unless the entrepreneur could find a location with access to networks.

\section{Socio-Cultural Issues in Mobile Phone Adoption}

Analysis of the data also drew out a number of emerging themes which indicated that social and cultural peer influences within their local environment, as well as within their business sector, flowed from the owner-managers' adoption of mobile phone technology. Hence, a number of socio-cultural benefits of mobile phone technology adoption were identified. For example, the interviewees spoke of their sense of pride in owing and using a mobile phone, how it raised their standing in the eyes of local people, and of their belief in the wider benefits to their business and the community that owning a phone could bring. Mobile technology aided communications beyond their local business environment, widening their links with business associates and extending their pool of customers. Family communications were also reported as enhanced, providing additional benefits from phone ownership. The mobile phone also generated a 'feel good' factor, enhancing confidence and happiness.

\section{Discussion}

In rural Ghana, typified by the Kwahu South district, the illiteracy rate is just under $45 \%$. Most residents are farmers (Ghana Statistical Service, 2012). The mobile phone has been seen as a gadget used by the educated (Frempong, 2009). However, the demystification of the perception of mobile phone usage has been addressed by the marketing activities of telecommunications companies in Ghana, contributing to its acceptance, adoption and usage (Acheampong et al., 2018).

This research in rural Ghana found that mobile phone technology adoption was driven by a number of factors, including poor telecommunication and transportation infrastructures. Other drivers included the nature of business competition and social change. The mobile phone enabled informal micro-entrepreneurs to stay connected with their customers and business partners. For such micro-businesses, mobile phones could be used as a diary to store customer information, to take sales orders, and make and accept payments, no matter the location of the customer, thereby facilitating trade and reducing banking bureaucracy (Jack 
and Suri, 2014). While the owner-managers recognised the business advantages of using mobile phone technology in the context of their own firms, they had limited understanding of platform technology. Nonetheless, they did make some use of it. Aligned with the findings of Bandeira and Rasul (2006) for small businesses in Africa with smartphones, the most common platforms known and used to facilitate businesses processes were social media message platforms such as WhatsApp.

The organisational context presented in this research study suggests that rural Ghanaian informal micro-entrepreneurships demonstrate technological readiness to adopt mobile phone technology, which they believe is beneficial to support business growth (Chakrabarti et al., 1990). Acting as information technology managers and decision-makers, the business owner-managers demonstrated technological readiness via their willingness and ability to understand and adopt this new technology. Recognising their current situation as lacking a sufficient communications infrastructure, the mobile phone presented a means of improving technology and communications (Wang et al., 2010) and it was recognised that it could be used as a resource (Oliveira and Martins, 2011).

\section{Implications for Theory}

The conceptual model in Figure 1 extends our understanding of the technological (T) and business (B) benefits of mobile phone technology gleaned from the literature (as depicted in the shaded grey boxes) by further including the specific socio-cultural benefits (SC) of mobile phone adoption by informal micro-entrepreneurships in rural Ghana as identified from this research. It therefore presents a contribution to knowledge and implications for theory by predicting a three-fold classification of the benefits of mobile phone technology adoption in supporting the business processes of informal micro-entrepreneurships in rural locations in developing countries. However, in order to mobilise these business process benefits, practical input is needed at national, organisational and local levels as highlighted in the proposed TBSC model.

As shown in Figure 1, the ease of use of the mobile phone technology, compatibility, simplicity of the design and the fact that entrepreneurs can easily learn how to use it, no matter their level of education, are proposed as the main technological benefits $(\mathrm{T})$ of mobile phone adoption in rural locations in developing countries. This is particularly relevant to developing economies considering the predominantly low educational backgrounds of ownermanagers of informal micro-entrepreneurships. The business benefits (B) include improved customer communications, sales facilitation and adaptability to different aspects of business 
processes. Figure 1's key contribution to knowledge and theory concerns the socio-cultural benefits (SC) of mobile phone adoption in the developing country rural context - the interviewees were excited and proud of their adoption of mobile technology, highlighting how it set them ahead in their communities and improved their access to wider communications. A strong belief in mobile technology's socio-cultural benefits was evident. Bringing these T, B and SC benefits together creates the three-fold TBSC conceptual model in Figure 1 with its connection strength, whereby the T, B and SC benefits can work together to underpin business process activity and identify practice implications.

\section{Implications for Practice}

Based on this TBSC framework, and as shown in Figure 1, a number of recommendations for practice can be proposed at government, industry and local levels. It is recommended that the government should develop policies to help informal micro-entrepreneurships in the villages and towns to grow their businesses due to their potential employment capabilities. To assist with this, the government could encourage and support informal micro-entrepreneurships to tap into the benefit of mobile phone technology and use it to support their businesses, especially in villages and towns in Ghana without direct landline communication facilities due to poor roads and geographical location issues.

These businesses are currently poorly recognised for their economic contribution, but they contribute greatly to economic growth both through employment and via minimisation of rural urban migration (Blankson et al., 2017). Their economic contribution could be improved, and potentially maximised, through government support for the adoption of mobile technology. For example, education and training in relation to understanding business processes is needed, particularly given the current lack of understanding of this aspect of business operations by those interviewed in this study, together with how the mobile phone can support and potentially improve business process stages.

It is also recommended that the telecommunications companies take steps to highlight the technological, business and socio-cultural benefits of mobile phone adoption in rural areas such as those in Ghana, as highlighted by this study. While of course this would increase telecommunications' penetration of hitherto untapped markets, thereby increasing sales, market share and company profitability, it also can be seen as providing more philanthropic outcomes by facilitating social and community benefits through improving the business processes of informal micro-entrepreneurships in rural communities. 


\section{Limitations and Further Research}

This study was small-scale and exploratory. Further research is necessary at local level with larger samples, in additional sectors, in other locations, and in larger business operations, to identify other factors influencing adoption and acceptance of mobile phone technology, the benefits that flow from it, and any problems in its use. De' et al. (2018) indicate in research by Information Communication Technology for Development on Africa that the usage of mobile phones to support socio-economic development and businesses is likely to rise. Hence, further research continuing in the same vein as this research study in rural Ghana could help to contribute not only academically to our knowledge of informal microentrepreneurships but also it would provide an avenue for policy makers and commercial technology businesses to access information. This could be used to help improve the technological competencies of informal micro-entrepreneurs and thereby raise future economic outcomes of developing countries.

\section{Conclusion}

Mobile phone adoption by informal micro-enterprises in rural Ghana provides technological, business and socio-cultural benefits. While informal micro-entrepreneurs are excited by their business use of mobile technology and are able to identify a number of clear benefits from using it, they do not fully understand its contribution to their business processes. As mobile phone usage grows within rural economies, this will contribute to successful economic outcomes. Informal micro-enterprise owners could potentially improve their businesses and economic outcomes through a greater understanding of mobile phone technology linked to business process stages. Practical action by the government and telecommunications firms, drawing upon further research at local level, could help to improve informal microentrepreneurships' use of mobile technology in supporting their business processes, thereby facilitating local economic outcomes and contributing to the growth of national economies in developing countries.

\section{References}

Acheampong, G. (2018), "Financial institution ties and survival of small commercial poultry farms (SCPFs) in Ghana”, Journal of Entrepreneurship in Emerging Economies, in press. 
Acheampong, G. and Esposito, M. (2014), "The nature of entrepreneurship in bottom of the pyramid markets", International Journal of Entrepreneurship and Small Business, Vol. 21 No. 4, pp. 437-456.

Acheampong, G. and Hinson, R.E. (2018), "Benefitting from alter resources: network diffusion and SME survival", Journal of Small Business \& Entrepreneurship, in press.

Acheampong, G., Braimah, M., Quaye, D.M. and Buame, S.K. (2014), "Impact of demographic factors on technological orientations of bop entrepreneurs in Ghana”, International Journal of Innovation and Technology Management, Vol. 11 No. 6, 1450037.

Acheampong, P. Zhiwen, L., Hiran, K.K., Serwaa, O.E., Boateng, F. and Bediako, I.A. (2018), "Examining the intervening role of age and gender on mobile payment acceptance in Ghana: UTAUT model”, Canadian Journal of Applied Science and Technology, Vol. 6 No. 1, pp. 141-151.

Adom, K. and Williams, C.C. (2014), "Evaluating the explanations for the informal economy in third world cities: some evidence from Koforidua in the eastern region of Ghana", International Entrepreneurship Management Journal, Vol. 10 No. 2, pp. 427-455.

Akanferi, A.A., Aziale, L.K. and Asampana, I. (2014), “An empirical study on mobile phone usage among young adults in Ghana: from the viewpoint of university students", International Journal of Computer Applications, Vol. 98 No. 5, pp. 15-21.

Aker, J. C. and Mbiti, M.B. (2010), "Mobile phones and economic development in Africa", Journal of Economic Perspectives, Vol. 24 No. 3, pp 207-232.

Amoako, I.O. and Matlay, H. (2015), "Norms and trust-shaping relationships among foodexporting SMEs in Ghana”, Entrepreneurship and Innovation, Vol. 16 No. 2, pp.123-134.

Ameyaw, B., Korang, J.A., Twum, E.T. and Asante, I.O. (2016), “Tax policy, SMEs compliance, perception and growth relationship in Ghana: an empirical analysis", British Journal of Economics, Management \& Trade, Vol. 11 No. 2, pp. 1-11. 
Asongu, S. (2013a), "How has mobile phone penetration stimulated financial development in Africa?", Journal of African Business, Vol. 14 No. 1, pp.7-18.

Asongu, S.A. (2013b), "The impact of mobile phone penetration on African inequality", AGDI Working Paper, No. WP/13/021, available at: https://www.econstor.eu/bitstream/10419/123599/1/agdi-wp13-021.pdf (accessed 17 April 2018).

Awiagah, R., Kang, J. and Lim, J.I. (2016), "Factors affecting e-commerce adoption among SMEs in Ghana", Information Development, Vol. 32 No. 4, pp. 815-836.

Bandeira, O. and Rasul, I. (2006), "Social networks and technology adoption in northern Mozambique", The Economic Journal, Vol. 116 No. 514, pp. 869-902.

Basole, R.C. and Karla, J. (2011), "On the evolution of mobile platform ecosystem structure and strategy”, Business \& Information Systems Engineering, Vol. 3 No. 5, pp. 313-322.

Blankson, C., Cowan, K. and Darley, W.K. (2017), "Marketing practices of rural micro and small businesses in Ghana: the role of public policy", Journal of Macromarketing, Vol. 38 No. 1, pp. 110-121.

Boafo, N.D., Kokuma, D.A. and Arthur, G. (2015), "Impact of mobile number portability on service delivery in the mobile telecommunication industry in Ghana; case study of Bharti Airtel Ghana Limited, Kumasi”, Developing Country Studies, Vol. 5 No. 6, pp.153159.

Bolton, J.E. (1971), Report of the Committee of Enquiry into Small Firms, Papers by Command 4811, HMSO, London.

Boudreau, K.J. and Hagiu, A. (2009), "Platform rules: multi-sided platforms as regulators", in Gawer, A. (Ed.), Platforms, Markets and Innovation, Edward Elgar, Cheltenham, UK, pp. 163-191. 
Boyce, C. and Neal, P. (2006), Conducting In-depth Interviews: A Guide for Designing and Conducting In-depth Interviews for Evaluation Input, Pathfinder International, Watertown, MA.

Braun, V. and Clarke, V. (2006), "Using thematic analysis in psychology", Qualitative Research in Psychology, Vol. 3 No. 2, pp. 77-101.

Bryman, A. and Bell, E. (2015), Business Research Methods, Oxford University Press, Oxford.

Buys, P., Piet, Dasgupta, S., Thomas, T.S. and Wheeler, D. (2009), "Determinants of a digital divide in sub-Saharan Africa: a spatial econometric analysis of cell phone coverage", World Development, Vol. 37 No. 9, pp. 1494-1505.

Chakrabarti, A.K., Tornatzky, L.G. and Fleischer, M. (1990), The Processes of Technological Innovation, Lexington Books, Lanham, MY.

Charles, R.O.K., Amankwaa, T. and Owusu, P. (2015), “A qualitative approach to examining the challenges of Ghanaian Small and Medium Scale Enterprises (SMEs): the case of new Juaben Municipality", International Review of Social Sciences and Humanities, Vol. 8 No. 2, pp. 9-19.

Ciborra, C.U. (1996), “The platform organisation: recombining strategies, structures, and surprises", Organization Science, Vol. 7 No. 2, pp. 103-118.

Cusomano, M.A. and Nobeoka, K. (1998), Thinking Beyond Lean: How Multi-Project Management is Transforming Product Development at Toyota and Other Companies, The Free Press, New York, NY.

De', R., Pal. A., Sethi, R., Reddy, S.K. and Chitre, C. (2018), "ICT4D research: a call for a strong critical approach", Information Technology for Development, Vol. 24 No. 1, pp.63-94.

DFID. (2016), “Guidance STAR-Ghana”, available at: https://www.gov.uk/guidance/starghana (accessed 17 April 2018). 
Domeher, D., Musah, G. and Hassan, N. (2017), "Inter-sectoral differences in the SME financing gap: evidence from selected sectors in Ghana”, Journal of African Business, Vol. 18 No. 2, pp. 194-220.

Duncombe, R. (2012), “Mobile phones for agricultural and rural development: a literature review and future research directions", Development Informatics Working Paper Series, No 50, Centre for Development Informatics, Institute for Development Policy and Management, SED University of Manchester, available at:

http://hummedia.manchester.ac.uk/institutes/gdi/publications/workingpapers/di/di_wp50.pdf (accessed 17 April 2018).

Esoko. (2015), “Connecting farmers”, available at: https://www.esoko.com/connectingfarmers/ (accessed 14 April 2018).

Frempong, G. (2009), "Mobile telephone opportunities: the case of micro- and small enterprises in Ghana", Info, Vol. 11 No. 2, pp. 79-94.

Furuholt, B. and Matotay, E. (2011), “The developmental contribution from mobile phones across the agricultural value chain in rural Africa", The Electronic Journal on Information Systems in Developing Countries, Vol. 48 No. 7, pp. 1-16.

Gawer, A. (2014), "Bridging differing perspectives on technological platforms: toward integrative framework", Research Policy, Vol. 43 No. 7, pp. 1239-1249.

Gawer, A. and Cusumano, M.A. (2014), "Industry platforms and ecosystems innovation", Journal of Product Innovation Management, Vol. 31 No. 3, pp. 417-433.

Grant, R. (2013), "Gendered spaces of informal entrepreneurship in Soweto, South Africa", Urban Geography, Vol. 34 No. 1, pp. 86-108.

Greenstein, S. (2009), “Open platform development and the commercial internet, in Gawer, A (Ed.), Platforms, Markets and Innovation, Edward Elgar, Cheltenham, UK, pp. 219-248. 
GSMA. (2014), "The mobile economy - sub-Saharan Africa, 2014”, available at: https://www.gsma.com/mobileeconomy/archive/GSMA_ME_SubSaharanAfrica_2014.pdf (accessed 14 April 2018).

GIPC. (2017), “Q 42017 GIPC Quarterly Investment Report”, Ghana Investment Promotion Centre, Vol. 13 No. 4, available at: http://www.gipcghana.com/press-andmedia/downloads/reports/24-q4-2017-gipc-quarterly-investment-report/file.html (accessed 22 August 2018).

Ghana Statistical Service. (2012), "2010 Population \& Housing Census Summary Report of Final Results", Ghana Statistical Service, Accra, Ghana, available at: http://www.statsghana.gov.gh/docfiles/2010phc/Census2010_Summary_report_of_final_resu lts.pdf (accessed 17 April 2018).

Hall, S.P. and Anderson, E. (2009), “Operating systems for mobile computing”, Journal of Computing Sciences in Colleges, Vol. 25 No. 2, pp. 64-71.

Hart, K. (1970), "Small-scale entrepreneurs in Ghana and development planning”, The Journal of Development Studies, Vol. 6 No. 4, pp. 104-120.

Hyrynsalmi, S., Suominen, A., Mäkilä, T. and Knuutila, T. (2014), "The emerging mobile ecosystems: an introductory analysis of android ecosystem", International Journal of EBusiness Research, Vol. 10 No. 2, pp. 61-81.

IEG World Bank (2014), “The Big Business of Small Enterprises: Evaluation of the World Bank Group Experience with Targeted Support to Small and Medium-Size Businesses, 200612", available at: http://ieg.worldbankgroup.org/Data/reports/sme_eval1_0.pdf (accessed 14 April 2018).

International Finance Corporation. (2011), "SMEs Small and medium enterprises, telling our story", Vol. 5 No 1, International Finance Corporation, available at: https://www.ifc.org/wps/wcm/connect/.../TOS_SME.pdf?MOD=AJPERES (accessed 17 April 2108). 
Islam, M.S. and Grönlund, Å. (2011), "Factors influencing the adoption of mobile phones among the farmers in Bangladesh: theories and practices", International Journal on Advances in ICT for Emerging Regions, Vol. 4 No. 1, pp. 4-14.

ITU. (2017), “Mobile Handset Use in Digital Financial Services”, International Telecommunications Union, available at: https://www.itu.int/en/ITUT/focusgroups/dfs/Documents/201703/ITU_FGDFS_Report-Mobile-Handset-Features.pdf (accessed 17 April 2108).

Jack, W. and Suri, T. (2014), "Risk sharing and transactions costs: evidence from Kenya's mobile money revolution", American Economic Review, Vol. 104 No. 1, pp.183-223.

Krishnan, V. and Gupta, S. (2001), “Appropriateness and impact of platform-based product development", Management Science, Vol. 47 No. 1, pp. 52-68.

Kusi, C., Opata, C.N. and Narh, T.-W.J. (2015), "Exploring the factors that hinder the growth and survival of small businesses in Ghana (a case study of small businesses within Kumasi metropolitan area)", American Journal of Industrial and Business Management, Vol. 5 No. 11, pp. 705-723.

Kwakwa, P.A. (2012), "Mobile phone usage by micro and small scale enterprises in semirural Ghana”, International Review of Management and Marketing, Vol. 2 No. 3, pp. 156164.

Lin, F. and Ye, W. (2009), "Operating system battle in the ecosystem of smartphone industry”, 2009 International Symposium on Information Engineering and Electronic Commerce, IEE Computer Society, available at: https://ieeexplore.ieee.org/stamp/stamp.jsp?tp=\&arnumber=5175193\&tag=1 (accessed 17 April 2018).

Meyer, M.H. and Lehnerd, A.P. (1997), The Power of Product Platforms: Building Value and Cost Leadership, The Free Press, New York, NY. 
Moore. J.F. (1993), "Predators and prey: a new ecology of competition”, Harvard Business Review, Vol. 71 No. 3, pp. 75-86.

Morgan, S.N. and Govender, K.K. (2016), "Conceptualizing loyalty in the South African mobile telecommunications industry”, Global Journal of Management and Business Research: E Marketing, Vol. 16 No. 6, pp. 1-6.

National Communications Authority. (2016), “Quarterly statistical bulletin on communications in Ghana", Vol. 1 No. 4, National Communications Authority, available at: https://nca.org.gh/assets/Uploads/stats-bulletin-4-final-13-06-17.pdf (accessed 17 April 2018).

Obeng, B.A., Robson, P. and Haugh, H. (2014), "Strategic entrepreneurship and small firm growth in Ghana", International Small Business Journal: Researching Entrepreneurship, Vol. 32 No. 5, pp. 501-524.

Ocloo, C.E., Akaba, S. and Worwui-Brown, D.K. (2014), "Globalization and competitiveness: challenges of small and medium enterprises (SMEs) in Accra, Ghana”, International Journal of Business and Social Science, Vol. 5 No. 4, pp. 287-296.

Odoom, R., Anning-Dorson, T. and Acheampong, G. (2017), “Antecedents of social media usage and performance benefits in small-and medium-sized enterprises (SMEs)", Journal of Enterprise Information Management, Vol. 30 No. 3, pp. 383-399.

Oliver, S. and Kandadi, K.R. (2006), "How to develop knowledge culture in organizations? A multiple case study of large distributed organizations", Journal of Knowledge Management, Vol. 10 No. 4, pp. 6-24.

Oliveira, T. and Martins, M.F. (2011), "Literature review on information technology adoption models at firm level”, The Electronic Journal Information Systems Evaluation, Vol. 14 No. 1, pp. 110-121.

Osei-Boateng, C. and Ampratwum, E. (2011), The Informal Sector in Ghana, Freidrich Ebert Stiftung, Bonn, Germany. 
PEW Research Center. (2015), "Cell phones in Africa: communication lifeline”, available at: http://www.pewglobal.org/2015/04/15/cell-phones-in-africa-communication-lifeline/ (accessed 21 April 2018).

Pierskalla, J.H. and Hollenbach, F.M. (2013), "Technology and collective action: the effect of cell phone coverage on political violence in Africa", The American Political Science Review, Vol. 107 No. 2, pp. 207-224.

Pine, B.J. (1993), Mass Customization: The New Frontier in Business Competition, Harvard Business School Press, Boston, MA.

Rao, D.M. (2012), "Mobile Africa report 2012: sustainable innovation ecosystems", available at: http://www.ictet.org/downloads/Mob_i3MuC0_zkwI.pdf (accessed 14 April 2018).

Robertson, D. and Ulrich, K. (1998), "Planning for product platforms", Sloan Management Review, Vol. 39 No. 4, pp 19-31.

Scarborough, N.M. and Zimmerer, T.W. (2011), Essentials of Entrepreneurship and Small Business Management, Prentice Hall, Upper Saddle River, NJ.

Sey, A. (2011), “We use it different, different': Making sense of trends in mobile phone use in Ghana", New Media \& Society, Vol. 13 No. 3, pp. 375-390.

Sørensen, C., de Reuver, M. and Basole, R.C. (2015), "Mobile platforms and ecosystems", Journal of Information Technology, Vol. 30 No. 3, pp. 195-197.

Tetteh, E.K. and Frempong, G.K. (2013), “Developing the rural economy of Ghana though micro and small enterprises (MSEs): issues and options", ATDF Journal, Vol. 5 No. 3/4, pp. 3-12.

Thomas, L.D.W., Autio, E. and Gann, D.M. (2014), “Architectural leverage: putting platforms into context”, Academy of Management Perspectives, Vol. 28 No. 2, pp.198-219. 
Tierney, C., Bawden, A. and Kunii, M. (2000), "Dynamic duo", Business Week, 23 October, p. 26.

Today Online (2017), "SMEs contribute 70\% to Ghana's GDP”, Today Online 18 January 2017, available at: https://www.todaygh.com/smes-contribute-70-ghanas-gdp/ (accessed 22 August 2018).

Tongco, M.D.C. (2007), "Purposive sampling as a tool for informant selection", Ethnobotany Research \& Applications, Vol. 5 No. 0, pp. 147-158.

Unicef stories of innovation. (2015), “AGOO: Ghana's interactive mobile platform to educate about Cholera, Ebola - and a catchy song!", available at:

http://unicefstories.org/2015/11/11/agoo-ghanas-interactive-mobile-platform-to-educateabout-cholera-ebola-and-a-catchy-song/ (accessed 14 April 2018).

Wang, Y.-M., Wang, Y.-S. and Yang, Y.-F. (2010), "Understanding the determinants of RFID adoption in the manufacturing industry", Technological Forecasting and Social Change, Vol. 77 No. 5, pp. 803-815.

Wennekers, S. and Thurik R. (1999), "Linking entrepreneurship and economic growth", Small Business Economics, Vol. 13 No. 1, pp. 27-56.

Wenner, G., Bram, J.T., Marino, M., Obeysekare, E. and Mehta, K. (2017), “Organizational models of mobile payment systems in low-resource environments", Information Technology for Development, DOI: 10.1080/02681102.2017.1311830

West J. and Wood, D. (2014), "Evolving an open ecosystem: the rise and fall of the Symbian platform”, in Adner, R., Oxley, J.E. and Silverman, B.S. (Eds.), Collaboration and Competition in Business Ecosystems, Emerald Group Publishing, Bingley, UK, pp. 27-67.

Wheelwright, S.C. and Clark, K.B. (1992), "Creating project plans to focus product development", Harvard Business Review, Vol. 70 No. 2, pp. 70-82. 
Xia, R., Rost, M. and Holmquist, L.E. (2010), "Business models in the mobile ecosystem", available at: http://www.mobilelifecentre.org/sites/default/files/ICMB-

GMR2010_Final_CameraReady.pdf (accessed 14 April, 2018).

Yin, R.K. (2013), Case Study Research: Design and Methods, Sage, London. 
Table 1: Thematic analysis of findings presenting representative quotations

\begin{tabular}{|c|c|c|c|c|c|}
\hline $\begin{array}{l}\text { Micro- } \\
\text { entrepreneur } \\
\text { business }\end{array}$ & $\begin{array}{l}\text { Factors influencing } \\
\text { mobile technology } \\
\text { adoption }\end{array}$ & Mobile technology used & Business process support & Problems encountered & $\begin{array}{l}\text { Emergent issues (socio- } \\
\text { cultural) }\end{array}$ \\
\hline Bakery & $\begin{array}{l}\text { Ease of use: "You know } \\
\text { like I told you that I } \\
\text { completed Middle School } \\
\text { in the 1960s (Secondary } \\
\text { School equivalent these } \\
\text { days) but yet I can use the } \\
\text { phone. I don't allow my } \\
\text { children to teach me } \\
\text { anything." }\end{array}$ & $\begin{array}{l}\text { Model - Nokia: "You see this } \\
\text { phone, I have used it for over } \\
\text { four years, it has dropped on } \\
\text { the ground so many times, but } \\
\text { I pick it up always without any } \\
\text { problems. The lines are clear, } \\
\text { with no breaks in } \\
\text { communications. I charge once } \\
\text { every three days!" } \\
\text { Platforms: "I have been told by } \\
\text { my children that the mobile } \\
\text { phone can be used for } \\
\text { Facebook but you see I have to } \\
\text { learn that as well." }\end{array}$ & $\begin{array}{l}\text { Communications and orders } \\
\text { logistics: "I use it to take my } \\
\text { bread orders which help me } \\
\text { plan how much I have to } \\
\text { bake. In the morning by } 7 \mathrm{am} \\
\text { customers will be calling me } \\
\text { on it and giving me orders of } \\
\text { how many quantities of bread } \\
\text { they want me to bake. To me, } \\
\text { the mobile phone is a God } \\
\text { sent item! Without it I could } \\
\text { not have known how I would } \\
\text { be doing my bread business." }\end{array}$ & $\begin{array}{l}\text { Network issues: "The } \\
\text { problems I do encounter } \\
\text { mostly are networks } \\
\text { connection. You see the } \\
\text { hill on the side of the road? } \\
\text { Sometimes I have to climb } \\
\text { it to get a clear network." }\end{array}$ & $\begin{array}{l}\text { Social communications: } \\
\text { "But for now, I use (it) to } \\
\text { keep my family in contact as } \\
\text { well as customers by } \\
\text { communicating and doing } \\
\text { business with them." } \\
\text { Feel good factor: "I have a } \\
\text { positive attitude towards the } \\
\text { phone because it has never } \\
\text { disappointed me." } \\
\text { Sense of pride: "I am proud } \\
\text { to have something I am } \\
\text { doing business with!" }\end{array}$ \\
\hline Bee keeping & $\begin{array}{l}\text { Lack of infrastructure: } \\
\text { "The government has so } \\
\text { many years promised us a } \\
\text { modern post office and } \\
\text { electricity for the town but } \\
\text { it has not materialised. We } \\
\text { thinking of land-line } \\
\text { telephone ... no way ... } \\
\text { this would take a hundred } \\
\text { years (laughs)." }\end{array}$ & $\begin{array}{l}\text { Models - Samsung and Tecno: } \\
\text { "The Samsung is my } \\
\text { smartphone and the Tecno is } \\
\text { my farm phone. I take the } \\
\text { Tecno with me to farms as it is } \\
\text { strong and catches the } \\
\text { MTN/Vodafone networks well. } \\
\text { I use the Samsung for doing } \\
\text { WhatsApp. I don't take that to } \\
\text { the farm." } \\
\text { Platforms: "I am aware that } \\
\text { there are platforms like } \\
\text { Facebook but I have been } \\
\text { thinking (it) is for the young } \\
\text { people! I don't know if I can } \\
\text { use it to sell but my son is } \\
\text { teaching me." }\end{array}$ & $\begin{array}{l}\text { Communications and sales } \\
\text { support: "I take pictures of } \\
\text { my honey in bottles and send } \\
\text { it to my customers. I } \\
\text { exchange messages via (it) } \\
\text { with other farmers." }\end{array}$ & $\begin{array}{l}\text { Network issues: "My } \\
\text { major issues are } \\
\text { connecting to networks in } \\
\text { this forest area and buying } \\
\text { credits. The internet is also } \\
\text { slow!" } \\
\text { Cost: "The cost of the } \\
\text { credits is expensive. You } \\
\text { buy let's say 20GHS } \\
\text { bundle and within a short } \\
\text { time, it is finished!" }\end{array}$ & $\begin{array}{l}\text { Social communications/feel } \\
\text { good factor: "Look, I have } \\
\text { posted my first message. } \\
\text { What could I have done } \\
\text { without the mobile phone? } \\
\text { You tell me? I am so } \\
\text { happy!" }\end{array}$ \\
\hline
\end{tabular}




\begin{tabular}{|c|c|c|c|c|c|}
\hline Herbal clinic & $\begin{array}{l}\text { Lack of infrastructure: } \\
\text { "You know this Kwahu } \\
\text { area on top of the hills. } \\
\text { There are no public } \\
\text { telephones and we don't } \\
\text { have the land-lines as well. } \\
\text { So, the only one we rely } \\
\text { on is the mobile phone." }\end{array}$ & $\begin{array}{l}\text { Model - Tecno: "I use the } \\
\text { Tecno because it is strong, } \\
\text { network is clear and it is } \\
\text { simple to use it." } \\
\text { Platforms: "I now use the } \\
\text { phone for WhatsApp, calling } \\
\text { my clients to ask of post- } \\
\text { diagnosis issues. I call my } \\
\text { customers on imo, and } \\
\text { WhatsApp. I know Facebook } \\
\text { and other platforms but I don't } \\
\text { use them to do business } \\
\text { because of my business." }\end{array}$ & $\begin{array}{l}\text { Client diagnostics: "I once } \\
\text { got a call from a man who } \\
\text { happened to be sexually weak } \\
\text { and was losing potency. He } \\
\text { wanted to book a private } \\
\text { appointment as he did not } \\
\text { want to come in when the } \\
\text { place was busy. I arranged a } \\
\text { private meeting and used the } \\
\text { mobile phone to keep him on } \\
\text { track on the diagnosis stages } \\
\text { until he got his potency } \\
\text { back." }\end{array}$ & $\begin{array}{l}\text { Battery life/cost: "The } \\
\text { problems I encounter most } \\
\text { are the battery life and also } \\
\text { the cost of the credit. } \\
\text { Sometimes, the battery dies } \\
\text { quick. On the credit, you } \\
\text { buy so much and in the } \\
\text { next few days you run } \\
\text { out." }\end{array}$ & $\begin{array}{l}\text { Sense of pride: "I am proud } \\
\text { and sure that I am using the } \\
\text { mobile phone because where } \\
\text { ever I am, my customers can } \\
\text { call me and I diagnose } \\
\text { them." } \\
\text { Wider communications: "I } \\
\text { can also give them } \\
\text { directions, and most } \\
\text { importantly I can } \\
\text { communicate with them } \\
\text { without the need for travel." }\end{array}$ \\
\hline $\begin{array}{l}\text { Palm oil } \\
\text { processing }\end{array}$ & $\begin{array}{l}\text { Ease of use: "Look, I } \\
\text { completed middle school } \\
\text { in the 1960s and did not } \\
\text { continue but yet I can use } \\
\text { the mobile phone like } \\
\text { those who have completed } \\
\text { universities." } \\
\text { Gaining on competitors: } \\
\text { "My competitors, I } \\
\text { believe, would not be able } \\
\text { to regulate supply stocks. I } \\
\text { am ahead of them here in } \\
\text { the business." }\end{array}$ & $\begin{array}{l}\text { Models - Samsung and Tecno } \\
\text { SQ16: "The Samsung is my } \\
\text { smartphone and the Tecno is } \\
\text { my farm phone." }\end{array}$ & $\begin{array}{l}\text { Communications, stock } \\
\text { control and orders logistics: } \\
\text { "You see, I call the farmers } \\
\text { who supply me with the palm } \\
\text { fruits which I process into the } \\
\text { oil. Sometimes, I get too } \\
\text { many and can't process them. } \\
\text { Sometimes I get too small } \\
\text { stocks when demand is for } \\
\text { palm oil is high on the } \\
\text { market. With the mobile } \\
\text { phone I am able to regulate } \\
\text { my orders. Do you think I } \\
\text { could have done this without } \\
\text { the phone?" }\end{array}$ & $\begin{array}{l}\text { Network issues: "The main } \\
\text { problem I have is the } \\
\text { network. I use MTN and } \\
\text { Vodafone. Sometimes, I } \\
\text { try the MTN it does not go } \\
\text { through, then I try the } \\
\text { Vodafone. You see, this is } \\
\text { a farming and a forest area. } \\
\text { I believe this is a } \\
\text { contributing factor." }\end{array}$ & $\begin{array}{l}\text { Belief in benefits: "I believe } \\
\text { in the mobile phone because } \\
\text { it has helped improve my } \\
\text { business." } \\
\text { Feel good factor: "When the } \\
\text { mobile phone is with you, } \\
\text { you feel confident. It does } \\
\text { help you to do so many } \\
\text { things! Put simply, I feel } \\
\text { confident and good using the } \\
\text { phone! The mobile phone is } \\
\text { my second wife! I believe } \\
\text { the phone was made for } \\
\text { me!" }\end{array}$ \\
\hline $\begin{array}{l}\text { Tailoring and } \\
\text { dressmaking }\end{array}$ & $\begin{array}{l}\text { Lack of infrastructure: "I } \\
\text { use the mobile phone to } \\
\text { receive payments of } \\
\text { clothes I have sown or } \\
\text { designed. I don't need to } \\
\text { go to the bank because of } \\
\text { mobile money." }\end{array}$ & $\begin{array}{l}\text { Models - Nokia and Tecno Y2: } \\
\text { "These phones are used } \\
\text { because the networks are clear } \\
\text { and the phones are rugged and } \\
\text { strong." } \\
\text { Platforms: "I also, through } \\
\text { WhatsApp, receive pictures of } \\
\text { designs from clients and I } \\
\text { prepare them as such." }\end{array}$ & $\begin{array}{l}\text { Communications and sales } \\
\text { support: "I check latest } \\
\text { clothing designs from the } \\
\text { internet and use it to design } \\
\text { for customers. Clients also } \\
\text { request certain styles through } \\
\text { the phone. For example, if } \\
\text { you want to surprise your } \\
\text { girlfriend with a nice design, } \\
\text { we can, through the mobile }\end{array}$ & $\begin{array}{l}\text { Network issues: "I use } \\
\text { MTN and Tigo. I have also } \\
\text { gone for Vodafone sim } \\
\text { card. The Tecno can accept } \\
\text { more than two sim cards so } \\
\text { I keep on changing them } \\
\text { for clarity of network." }\end{array}$ & $\begin{array}{l}\text { Belief in benefits: "I am a } \\
\text { very confident woman } \\
\text { because I know how to use } \\
\text { the mobile phone to do my } \\
\text { business". Previously, I } \\
\text { thought the mobile phone } \\
\text { was a rich man's phone but } \\
\text { now I know everybody can } \\
\text { use it. The mobile phone } \\
\text { keeps my family and my }\end{array}$ \\
\hline
\end{tabular}




\begin{tabular}{|l|l|l|l|}
\hline & & $\begin{array}{l}\text { phone send you samples, for } \\
\text { you to make a choice, while } \\
\text { you don't need to come here. } \\
\text { You can send us her } \\
\text { measurements through the } \\
\text { phone, and we will design the } \\
\text { clothes for you to spice up } \\
\text { your relationship! Finally, I } \\
\text { communicate with clients on } \\
\text { the phone on collection and } \\
\text { delivery times. Clients pay us } \\
\text { through the mobile phone." }\end{array}$ \\
\hline
\end{tabular}


Figure 1: The TBSC conceptual model of mobile phone technology adoption in supporting informal rural micro-entrepreneurships in developing countries

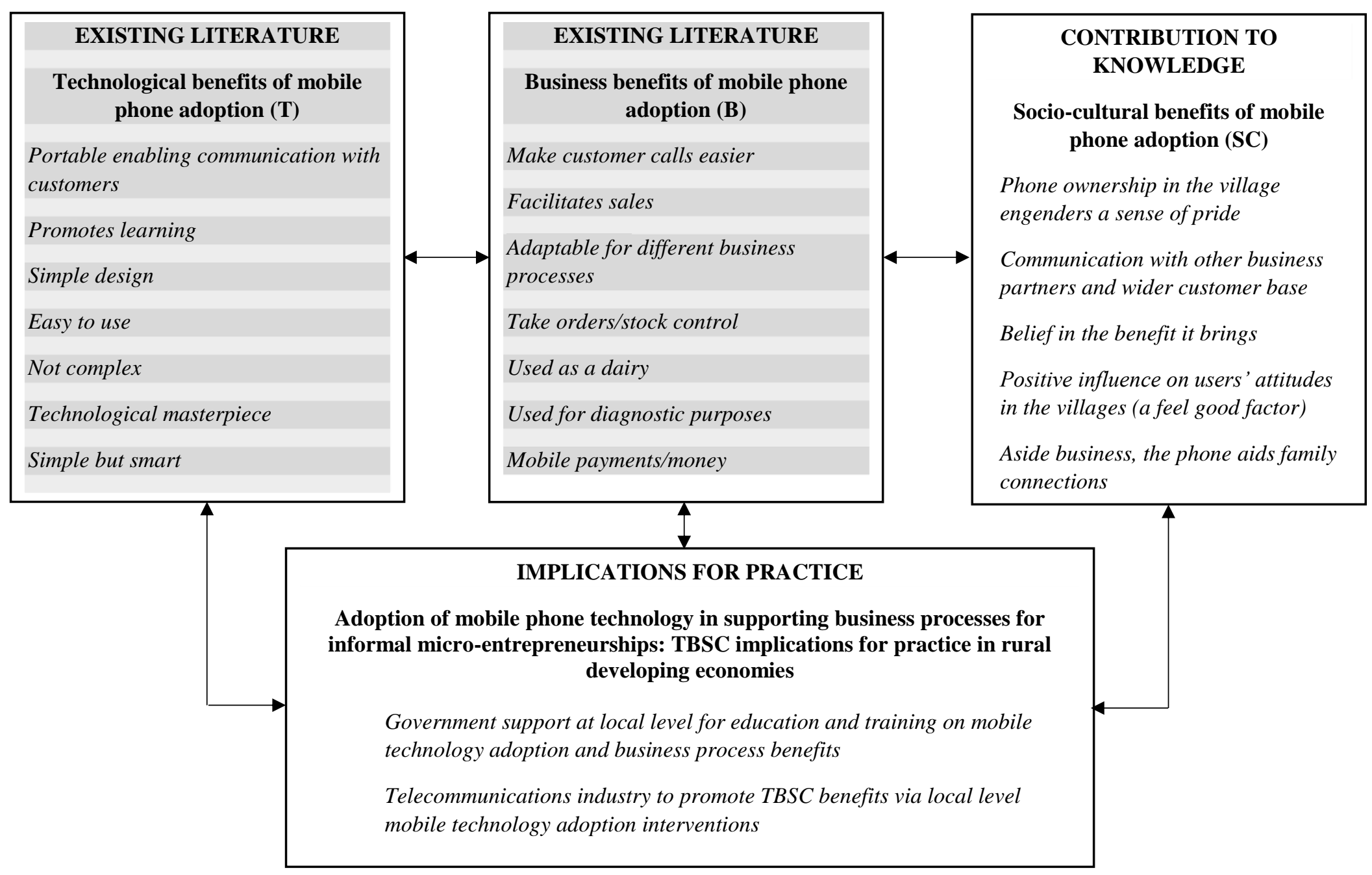




\section{Appendix 1: Semi-structured interview schedule}

Business background:

How did you get into this business; how long have you been doing this? How many staff members do you have? Is this your main business? Do you have branches elsewhere? Annual turnover?

\section{Use of mobile technology:}

What influenced you to go for a mobile phone rather than a land-line? Apart from making calls, messages, WhatsApp, what else do you use the phone for? How many mobile phones do you have? What brands are they? What networks have you subscribed to and why? Is the phone opened to any network or just for specific provider e.g. MTN/Vodafone/Tigo? Do you prefer to use more than one network? If so, why? Do you have network issues? How do you address these? How many SIM cards does this phone take? What is the battery life, how often do you charge it? How do you charge the batteries? Have you changed anything on the phone design or the make, so that it makes it easier to use? If so, how and why? Which aspects of your business do the changes on the mobile phone help the most?

\section{Learning and development:}

Did you have any knowledge of using mobile phones before buying the one you are currently using? Which features on the phone made learning to use it easier? What skills have you learned since you started using the phone? Are there competencies you have developed in using mobiles that other micro-businesses lack? Are these competencies affirming the reasons why you adopted the use of the mobile phone technology?

\section{Platforms and business processes:}

Do you know of any mobile phone platforms? Do your businesses use a mobile platform? If so what is it? To what extent do you believe that the mobile phone platform available on your phone is helping to improve the way that you do your business? What problems do you encounter when using the phone to facilitate your business process? How have platforms helped to improve the business processes?

\section{Business benefits:}

Please tell me three things that you believe made you adopt a mobile phone to be used for your business. What specifically do you use the mobile phone for? In what ways has your business improved using the phone? Which aspect of the business has the phone helped to improve most? How did the mobile phone technology help your business get to where you are today? Could you have done your business without the mobile phone and its platforms? 


\section{Appendix 2: Background case study information}

Bakery:

The owner-manager started her bakery business when she dropped out of school after the death of the father. She started baking on a small scale, selling to the people in her rural village. Her business has since expanded and she now has customers in other local villages and nearby towns. She is 38 years old, has four staff members and a driver who is in charge of the delivery and suppliers to her customers.

\section{Bee keeping:}

The owner-manager is a farmer setting up his bee hives in rural palm plantation farms. He started his business 15 years ago. He is 55 years old and a teacher by profession. He has three staff supporting his bee keeping enterprise as he spends the majority of his time teaching. Herbal clinic:

The owner-manager acted as an understudy to her grandmother who was a traditional herbalist and who started the herbal practice. After her grandmother passed away, she took over the clinic and has managed it ever since. She is 45 years old, is polytechnic graduate and she currently has two staff members.

Palm oil processing:

In this palm oil extraction business, the owner-manager buys palm fruits and processes them using basic extraction equipment. The red palm oil is separated from the kernel and packaged into drums for sale to companies. Kernels are also processed again to obtain palm kernel oil which is sold for individual consumption and also to companies that need it to facilitate their production. The owner-manager is 54 years old and has a secondary school education. He has been doing business for the past 30 years. He currently has 11 staff of which six are permanent and five are casual workers.

Tailoring and dressmaking:

The owner-manager has been running her business for the past 20 years. Customers buy the fabric they want, and then visit the shop for the bespoke or made-to-fit designs to be made up for them. The owner-manager is 42 years old and has a secondary school education. She currently has five staff members who support her in designing and sewing the clothes. 